\title{
Erratum to: The epidemiology of CuZn-SOD mutations in Germany: a study of 217 families
}

Malessa Rabe $\cdot$ Ansgar Felbecker $\cdot$ Stefan Waibel $\cdot$ Peter Steinbach · Pia Winter · Ulrich Müller •

Albert C. Ludolph

Published online: 29 April 2010

(C) Springer-Verlag 2010

Erratum to: J Neurol

DOI 10.1007/s00415-010-5512-9

Unfortunately, the author group was published with errors.

The complete author list is given here.

Malessa Rabe, Ansgar Felbecker, Stefan Waibel, Peter Steinbach, Pia Winter, Ulrich Müller, Albert C. Ludolph

The online version of the original article can be found under doi:10.1007/s00415-010-5512-9.

M. Rabe - A. Felbecker - S. Waibel · P. Steinbach ·

A. C. Ludolph $(\bowtie)$

Department of Neurology, University of Ulm,

Oberer Eselsberg 45, 89081 Ulm, Germany

e-mail: albert.ludolph@rku.de

P. Winter · U. Müller

Department of Genetics, University of Gießen, Gießen, Germany 